\title{
The Growth of Bosnian Pine (Pinus hedreichii Christ.) at Tree- Line Locations from Kosovo and its Response to Climate
}

\author{
Faruk Bojaxhi ${ }^{1 *}$, Elvin Toromani ${ }^{2}$
}

(1) Kosovo Forest Agency, Zenel Saliu street 1/a, 10000 Pristina, Kosovo; (2) Agricultural University of Tirana, Faculty of Forestry Sciences, Koder Kamez, AL-1029 Tirana, Albania

*Correspondence: e-mail: farukbojaxhi@yahoo.com

\begin{abstract}
Citation: BOJAXHI F, TOROMANI E 2016 The Growth of Bosnian Pine (Pinus heldreichii Christ.) at Tree Line Locations from Kosovo and its Response to Climate. South-east Eur for 7 (2): 109-118. DOI: https://doi.org/10.15177/seefor.16-10
\end{abstract}

Received: 20 Mar 2016; Revised: 10 May 2016; 9 Jun 2016; Accepted: 20 Jun 2016; Published online: 20 Jul 2016

\begin{abstract}
Background and Purpose: Pinus heldreichii Christ. is a sub-endemic species occurring at tree-line locations in Kosovo and covering an area of 2500 ha. In high elevation sites radial growth is mainly controlled by low temperatures. The main purpose of this study was the analysis of radial growth of $P$. heldreichii and its response to local climate conditions.

Materials and Methods: Research sites comprise of three high elevation stands of $P$. heldreichii with specific site conditions. Core samples were collected from 98 healthy dominant and co-dominant trees at breast height using increment borer. They were prepared and cross-dated using standard dendrochronological methods, while tree-ring widths were measured to the nearest $0.001 \mathrm{~mm}$ using the TSAP software. The ARSTAN program was used to standardize the tree-ring widths and to calculate dendrochronological statistical parameters. The growth-climate relationship was investigated using bootstrapped correlation function analysing the residual chronologies of each sampled site as a dependent variable and the climatic data from May of the (n-1) year up to the October of the $n$ year for the common period 1951-2013 as an independent variable. Results: The length of Bosnian pine chronologies ranged from 175 to 541 years. All chronologies had high values of firstorder autocorrelation indicating that radial growth of $P$. heldreichii is affected by the climate conditions of the previous growing year. Koritnik chronology had the highest values of the mean sensitivity due to the influence of drought stress. This conclusion is also supported by the result of growth-climate relationship where radial growth is negatively correlated with June temperatures and positively associated with July and August precipitation. We found that radial growth of young trees from Koritnik site is limited by the combined effect of temperatures and summer drought stress. In high elevation sites, temperature is expected to control the growth of $P$. heldreichii, but this effect is becoming more restrictive with age. The positive correlation between radial growth and winter temperatures suggests that favorable thermal conditions during winter months influence snow melting or soil moisture availability and indirectly affect the radial growth of $P$. heldreichii at all three sampled sites.

Conclusions: The first tree-ring width chronologies from Kosovo are an important step towards a denser tree ring network in the Balkan region. Growth-climate relationships indicated that for P.heldreichii growth does not depend only on one single dominant factor, but also on various combinations of precipitation and temperature resulting in different climatic sensitivity. Our results provide an important basis for additional tree-ring parameters such as maximum latewood density and stable isotope ratios to be processed, improving the level of knowledge about $P$. heldreichii's response versus site conditions.
\end{abstract}

Keywords: Pinus heldreichii, growth - climate relationship, tree-line, bootstrap correlation 


\section{INTRODUCTION}

The direct and indirect effects of global warming on forest ecosystems represent a challenge for human well-being in the near future [1]. Warming trends can influence vegetation patterns by modifying the start and the duration of the growing season, and abrupt air temperature increase can alter growth responses [2].

Climate changes are expected to alter the distribution of tree-line species in mountainous areas, and most predictive models forecast an upward displacement of species, tracking increases in temperatures [3, 4]. However, not all species respond in the same way to climate changes. Special attention must be paid also to species such as Pinus heldreichii Christ., which grows in high elevations making it more sensitive to temperature oscillation.

Pinus heldreichii Christ (syn. P. leucodermis Antoine) is a sub-endemic species occurring in isolated subalpine locations in the Balkan Peninsula and Southern Italy. The Balkan Peninsula plays a key role as a climatic transition zone between western and eastern Mediterranean and also between the Mediterranean and Central European synoptics [5-9].

Previous studies on $P$. heldreichii have been conducted in Bulgaria [10, 11], Greece [12, 13], and Albania [14], exploring growth-climate relationship of this high elevation species. Moreover, summer temperature was reconstructed (17682008) based on maximum latewood density measurements of $P$. heldreichii trees from a high-elevation stand in the Pirin Mountains in Bulgaria [15]. In Albania, a 1391-year tree-ring width chronology (617-2008) was developed and maximum density measurements were acquired on living and dead $P$. heldreichii trees [14].

The overall forest area covered by $P$. heldreichii in Kosovo is accounted to 2150 ha, and it is mostly mixed with species like silver fir (Abies alba Mill.). Some natural forest stands of this species exist in Kosovo, situated in Prevalla (PRE), Koritnik (KO) and Decani (DE) regions respectively, but no dendroclimatic study has been done up to this moment.

The high conservational value of such taxa additionally increases the importance of studies based on tree-ring width that allow a better understanding of the radial growth-climate relationship, as well as the ecophysiological requirements of trees $[16,17]$. Changes in annual tree-ring width growth could be due to the effect of environmental conditions, climate and anthropogenic disturbances. To analyze the influence of climatic conditions on growth of coniferous species at the tree-line locations, tree-ring widths (TRW) and wood density chronologies are used $[18,19]$. Intra-annual radial growth rates and duration in trees of $P$. heldreichii differ greatly in relation to site conditions. Thus, better knowledge of the relationship between TRW development and climate is needed to improve the current level of dendroclimatic studies in Kosovo and Albania. In this study, we investigated the responses of $P$. heldreichii growth to local climatic variations in three high elevation sites from Kosovo. The aim of this paper was (i) to study the growth - climate relationship of $P$. heldreichii and (ii) to identify the main climatic factors driving its radial growth.

\section{MATERIALS AND METHODS}

\section{Study Areas and Sample Sites}

The study areas are natural ecosystems located close to the upper distribution limit of Bosnian pine at Prevalla $\left(42^{\circ} 11^{\prime} \mathrm{N}\right.$, $20^{\circ} 57^{\prime} \mathrm{E} ; 1945 \mathrm{~m}$ a.s.l), Decan (42 $36^{\prime} \mathrm{N}, 20^{\circ} 14^{\prime} \mathrm{E} ; 1830 \mathrm{~m}$ a.s.l), and Koritnik $\left(42^{\circ} 04^{\prime} \mathrm{N}, 20^{\circ} 31^{\prime} \mathrm{E} ; 1815 \mathrm{~m}\right.$ a.s.l) in western and

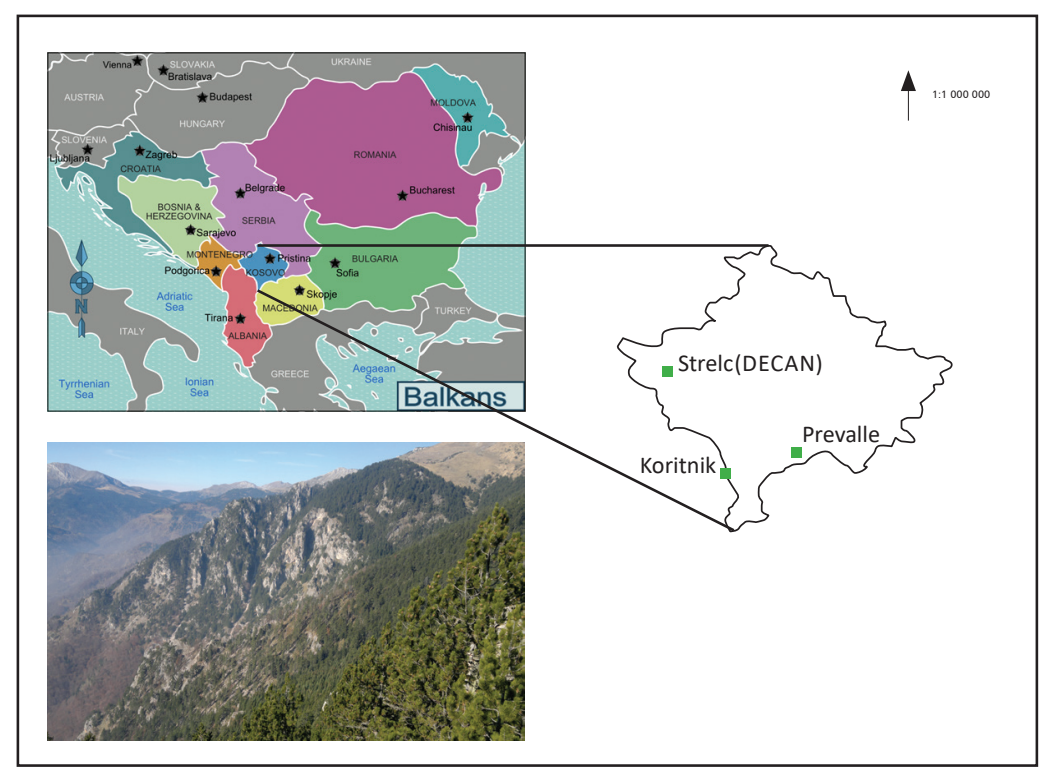

FIGURE 1. The location of Kosovo (upper left side) in Europe and of the sampled sites (right side) 
TABLE 1. Site characteristics of the sampled sites

\begin{tabular}{|c|c|c|c|c|c|}
\hline Sampled site & Latitude / longitude & $\begin{array}{l}\text { Altitude } \\
\text { (m a.s.I.) }\end{array}$ & Aspect & Soil / rock formation & Sampled trees \\
\hline $\begin{array}{l}\text { Prevalle } \\
\text { (PRE) }\end{array}$ & $\begin{array}{l}\text { N } 42^{\circ} 11^{\prime} 01.3^{\prime \prime} \\
\text { E } 20^{\circ} 57^{\prime} 42.0^{\prime \prime}\end{array}$ & 1945 & SW & $\begin{array}{l}\text { Typical rendzina soils on } \\
\text { limestone bedrock }\end{array}$ & 30 \\
\hline $\begin{array}{l}\text { Decan } \\
\text { (DE) }\end{array}$ & $\begin{array}{l}\text { N } 42^{\circ} 36^{\prime} 19.8^{\prime \prime} \\
\text { E } 20^{\circ} 14^{\prime} 52.5^{\prime \prime}\end{array}$ & 1830 & NW & $\begin{array}{l}\text { Brown soils on limestone } \\
\text { bedrock }\end{array}$ & 38 \\
\hline Koritnik (KO) & $\begin{array}{l}\text { N } 42^{\circ} 04^{\prime} 46.5^{\prime \prime} \\
\text { E } 20^{\circ} 31^{\prime} 58.6^{\prime \prime}\end{array}$ & 1815 & NW & $\begin{array}{l}\text { Grayish-brown rendzina soils } \\
\text { on limestone bedrock }\end{array}$ & 30 \\
\hline
\end{tabular}

southern Kosovo (Figure 1) (Table 1). Soil types are based on limestone bedrocks creating leptosols (rendzinas) and brown soils on higher slopes with slight differences among sites. At all sampled sites Bosnian pine is the dominant species while the ground vegetation comprises of species such as: Sesleria autumnalis Ard., Brachypodium sylvaticum Huds., Carex humilis Leyess., Thymus balcanus L., Fragaria vesca L., Festuca heterophylla Lam., Dactylus glomerata L., etc. These forest stands grow under the effect of Continental climate with some influences of Mediterranean climate in the southern Kosovo. Mean annual temperature varies among sampled sites and ranges from $8.0^{\circ} \mathrm{C}$ (PRE-site) to $8.3^{\circ} \mathrm{C}$ (KO-site), while the longterm mean annual precipitation ranges from $791 \mathrm{~mm}$ (DEsite) to $1029 \mathrm{~mm}$ (KO-site) (CRU TS3.22 dataset, period 19012013). The weather in the sampled site is characterized by a non-uniform rainfall distribution, with summers that are very short and cold as well as with cold winters with lots of snow.
Maximum precipitation falls from October to December, while the minimum rainfall is recorded from July to August (Figure 2). Moreover, natural forest stands of $P$. helderichii grow on sites with different slope aspects ranging from NW for DE and KO sites to SW for PRE site.

\section{Tree-Ring Chronology Development}

The core samples were collected from old dominant and co-dominant trees with healthy trunks and no sign of human interference. We extracted two cores from each tree at breast height $(1.3 \mathrm{~m})$ when possible. Otherwise we tried to avoid compression wood due to steep slopes, compiling a set of 98 new samples from all sites. Core samples were air-dried and glued onto wooden holders and subsequently sanded to ease growth ring identification [20]. The TRW were measured at $0.001 \mathrm{~mm}$ precision, with a LINTAB 6 (RINNTECH, Heidelberg) system and TSAP-Win Scientific software. Then they were cross-
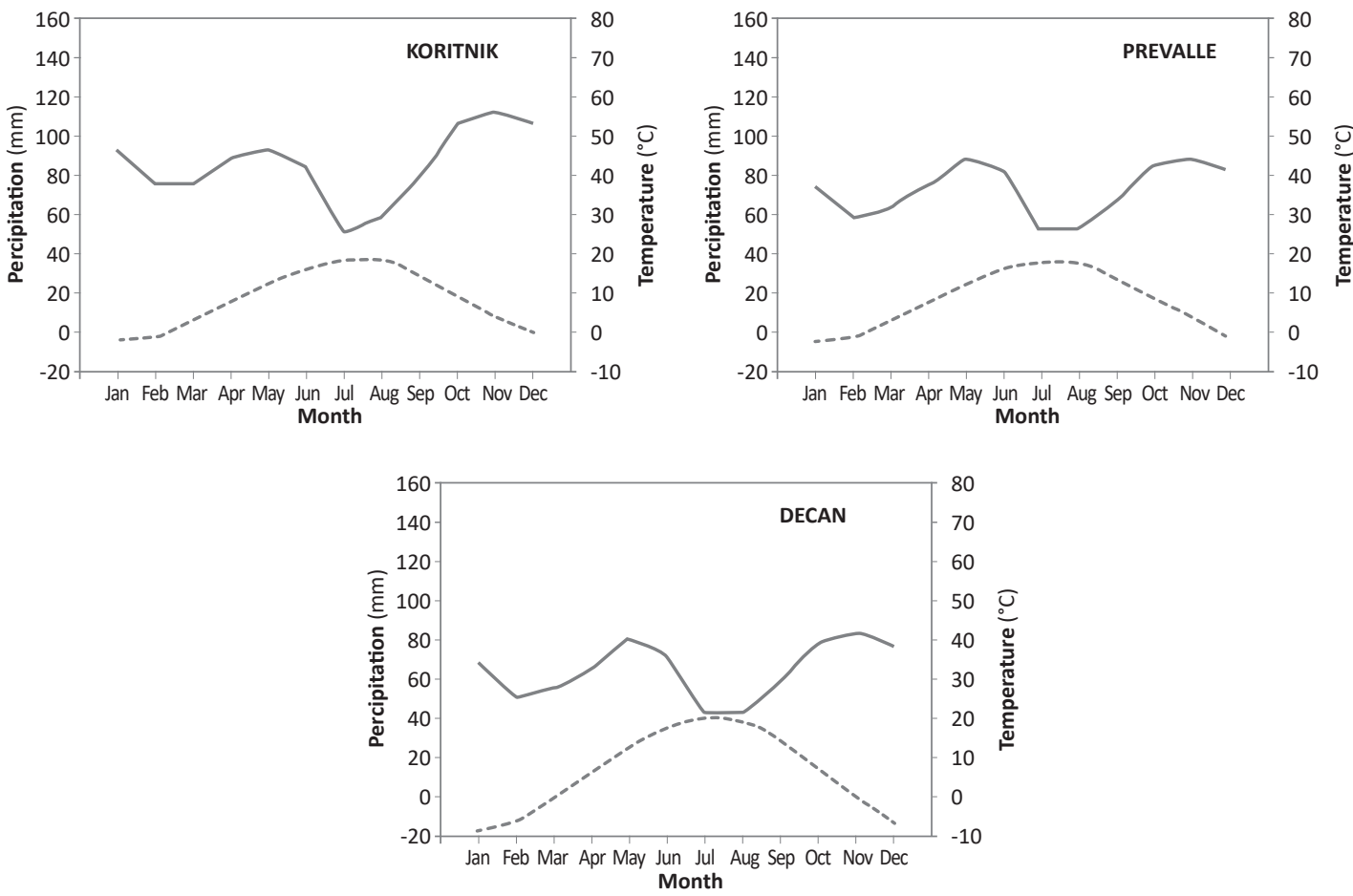

FIGURE 2. Climatic diagrams of the studied sites based on the CRU TS 3.22 data. Dashed line shows temperature, while solid line precipitation values. 
dated visually and confirmed statistically using the software COFECHA [21]. The individual raw tree-ring series were standardized in a two-step procedure using ARSTAN software $[22,23]$. First, a negative exponential curve was fitted to the ring series. For second de-trending a cubic smoothing spline with a $50 \%$ frequency-response of 30 years was used to reduce the non-climatic variation in tree-ring series. This way most of the low-frequency variability in each tree-ring series that is assumed to be unrelated to climate, such as tree aging and forest stand development, was removed. The observed values were divided by predicted values to produce dimensionless indices. The indices were then averaged to obtain site chronologies using a bi-weight robust mean [24]. Common signal in chronology was estimated using expressed population signal (EPS >0.85) which indicates to what extend the sample size is representative of a theoretical infinite population [25]. Residual chronologies are commonly used in dendroclimatic studies because the removal of serial autocorrelation is required for growth- climate analysis.

\section{Climate Data}

Total monthly precipitation and mean monthly temperatures were provided from the CRUTS3.22 dataset, with a spatial resolution of $0.5 \times 0.5^{\circ}$ (http://www.cru.uea.ac.uk/) [26] reaching back to 1901 . The only available local climate records belong to Prizreni town, but they were not sufficiently reliable due to the short length of series (series length 1977-1987 and 2009-2014), missing values (from 1988 to 2008) and the lack of homogenization. CRU data used in this study were extracted from the database of KNMI Climate explorer (http://climexp. $\mathrm{knmi} . \mathrm{nl} /$ ) for the region encompassed by the coordinates $41.5^{\circ}$ $43.5^{\circ} \mathrm{N}$ and $20^{\circ}-22^{\circ} \mathrm{E}$. However, to the best of our knowledge the CRU climatic dataset is the best available dataset to test long-term changes in radial growth as related to climate in several countries. The gridded climate data for the period 1951-2013 were considered reliable for the growth-climate analysis, because weather station density is high and stable for interpolation of CRU dataset and climate data have been checked and tested for homogeneity.

\section{Growth-Climate Relationship Analysis}

To quantify the relationship between residual site chronologies and monthly climate data (mean monthly temperatures, total monthly precipitation), we calculated bootstrapped correlation coefficients for the common period 1951-2013. The growth-climate relationship analysis was performed with DENDROCLIM2002 software [27]. Bootstrapped correlations were calculated between TRW residual chronologies of Bosnian pine at three sites which were analysies as dependent variables and the climatic data (independent variables) using a 18-month window from May of the year prior to tree-ring width formation (year t - 1) until October of the year of growth (year $t$ ). Correlation coefficients were considered significant if they exceeded, in their absolute value, half of the difference between the $97.5^{\text {th }}$ quantile and the $2.5^{\text {th }}$ quantile of 1000 estimates calculated in the bootstrapping procedure [27].

\section{RESULTS}

\section{Tree-Ring Chronologies}

The length of master chronologies varies among sites. Thus, the chronology from DE- site was the longest with 541 years, spanning throughout the period 1474-2014 with a replication of more than 34 trees from 1770 onwards. The chronology from KO-site was the shortest, 176 years long, with a sample replication of 25 trees, while the chronology from PRE was 243 years long spanning throughout the period 1776-2014 with a sample replication of 25 trees from 1920 onwards (Figure 3, Table 2). The year-to-year persistence (AC) was higher at higher elevation site (PRE) while the inter-annual variability (MS) of growth resulted as greater at KO which suggests that climatic constraints on species growth are more important for this site. All chronologies were correlated $(p<0.01)$ with each other for the common period 1840-2014, but the degree of agreement and similarity appears to be higher between DE and other chronologies, and slightly lower among PRE and KO chronologies. These results indicate that the degree of agreement in radial growth appears to be unrelated to the vicinity between sites (Table 3). Although KO and PRE sites are close to each other and trees belong to the same age class, the low agreement between both site chronologies might be due to slope aspect.

TABLE 2. Statistical parameters of three $P$. hedreichii chronologies from Kosovo

\begin{tabular}{lccc}
\hline \multicolumn{1}{c}{ Statistical parameters } & Decan (DE) & Koritnik (KO) & Prevalle (PRE) \\
\hline Time span & $1474-2014$ & $1840-2014$ & $1776-2014$ \\
Total years & 541 & 176 & 243 \\
Number of trees in chronology & 34 & 25 & 25 \\
Mean age & $240 \pm 69$ & $147 \pm 18$ & $116 \pm 20$ \\
Mean tree-ring width (mm) & 1.06 & 1.81 & 2.13 \\
Standard deviation & 0.498 & 0.872 & 0.907 \\
Skewness & 1.037 & 0.995 & 0.547 \\
Mean Sensitivity (MS) & 0.224 & 0.245 & 0.212 \\
AC (1) & 0.769 & 0.751 & 0.783 \\
EPS $>0.85$ since & 1770 & 1876 & 1920 \\
\hline
\end{tabular}



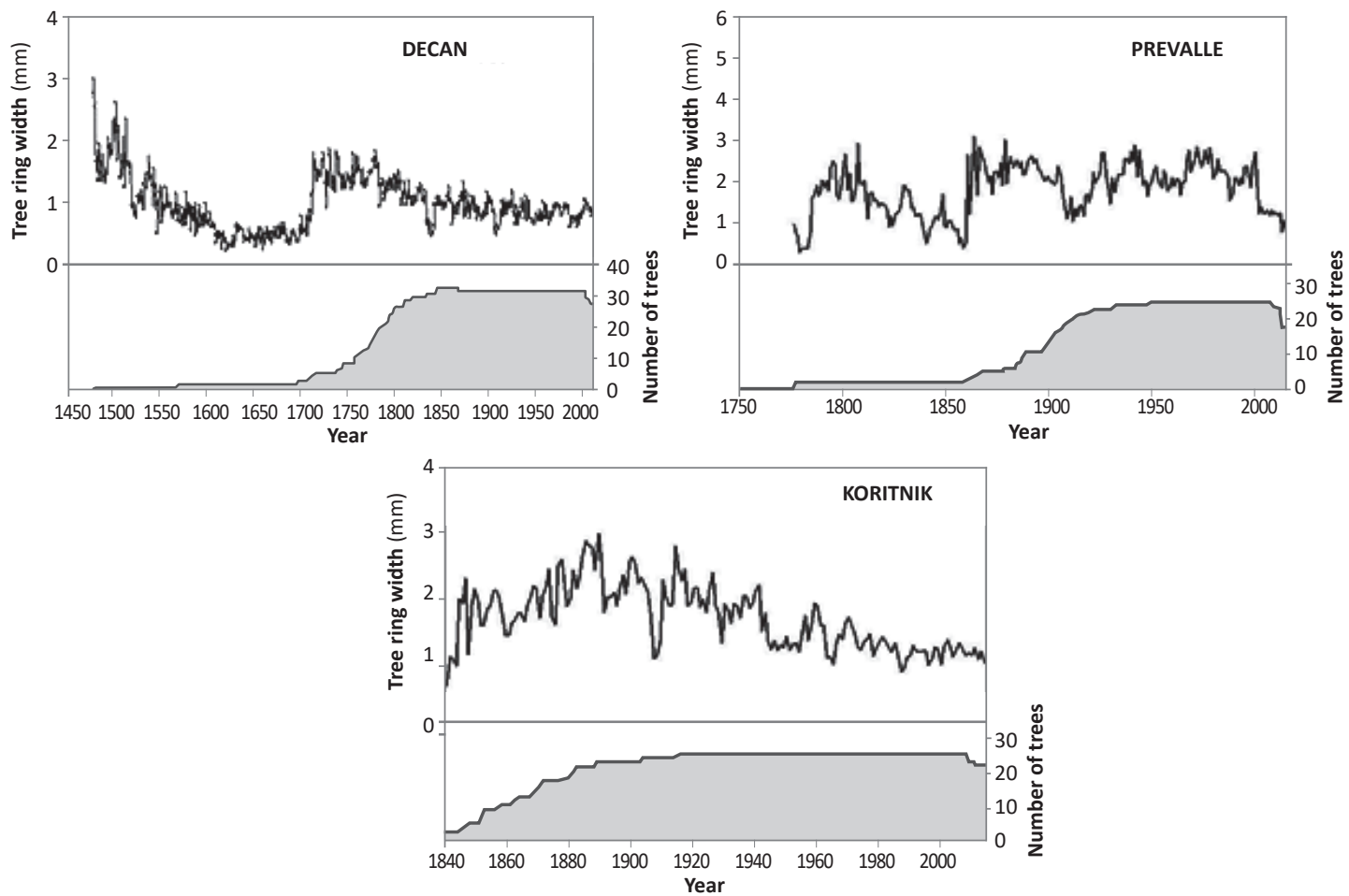

FIGURE 3. Raw tree-ring width chronologies of Bosnian pine (P. heldreichii Christ.) from Decan, Prevalla and Koritinik. Upper part in each graph shows the raw tree-ring width chronology while lower part shows tree replication in respective site chronologies

\section{Growth-Climate Relationship}

We tested the response to temperatures and precipitation from the previous year's May to the current October of TRW formation for the three site chronologies (Figure 4). All correlations computed over the common period 19512013 were not high (maximum r-value: 0.37 for DE versus July precipitation). From all 108 correlations calculated for temperature and precipitation together, only $16 \%$ reached the $95 \%$ significance level. These facts underline the existence of divergent correlation patterns among the three studied sites emphasizing the important role of local conditions on Bosnian pine's growth. Regarding the site-specific patterns, the DE chronology seemed to be slightly more sensitive to current summer precipitation variations than other sites.

In case of KO site, tree growth was correlated negatively to the temperatures of previous July, August and September as well as June of the current growing year. Moreover, growthclimate relationship showed that $P$. heldreichii's growth was positively correlated with previous August and negatively associated with current May precipitation. The negative response to previous summer temperatures and the positive correlation to previous July precipitation suggest that Pinus heldreichii's growth from KO site is mainly controlled by drought conditions.

Bootstrap correlation analysis showed that PRE chronology was correlated positively to the temperatures of current January and February and the precipitation of previous May, October and July of the current growing year. An adverse relationship was noted with previous June and current April precipitation. The main climatic factors stimulating growth in this high-elevation site were favorable temperatures during

TABLE 3. Comparison between all three P. heldreichii chronologies from Kosovo

\begin{tabular}{lcccccc}
\hline & \multicolumn{2}{c}{ Prevalle (PRE) } & \multicolumn{2}{c}{ Decan (DE) } & \multicolumn{2}{c}{ Koritnik (KO) } \\
\cline { 2 - 7 } Sampled sites & t-BP & GLK \% & t-BP & GLK \% & t-BP & GLK \% \\
\hline Prevalle & - & - & 7.1 & 66 & 6.8 & 59 \\
Decan & 7.1 & 66 & - & - & $\mathbf{1 2 . 3}$ & $\mathbf{7 1}$ \\
Koritnik & 6.8 & 59 & $\mathbf{1 2 . 3}$ & $\mathbf{7 1}$ & - & - \\
\hline
\end{tabular}




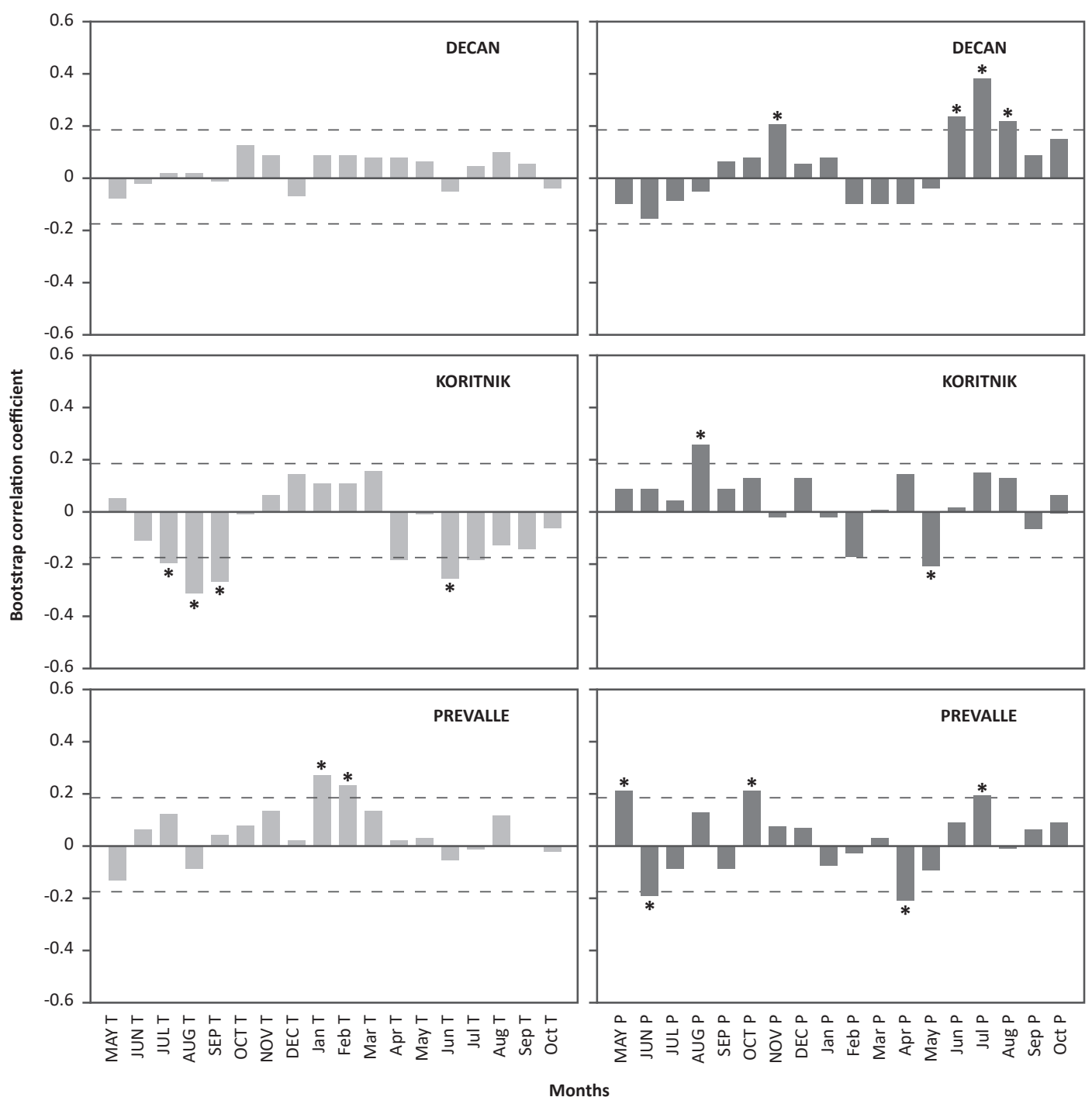

FIGURE 4. Bootstrap correlation coefficients between residual chronologies and temperature (left) and precipitation (right) asterisks on the top of the bars indicate $95 \%$ significance level of the correlation coefficient

current January and February associated with a positive water balance in July. Growth-climate relationships over the last 62 years, however, indicate that tree-ring formation in KO and PRE sites does not depend on one single dominant factor, but rather on various combinations of precipitation and temperature in certain months resulting in a temporal alteration of climatic sensitivity.

\section{DISCUSSION}

\section{Chronology Characteristics}

We performed this investigation to assess the impact of climate on Bosnian pine's growth and to evaluate its response.
We were able to develop three TRW chronologies from Kosovo region reaching a maximum of 541 years back in time (from 1474 to 2014). Although the replication of the dataset decreases back in time, the EPS threshold varies among sites spanning from 1770 for DE-site to 1920 for PRE site. The quality of such chronologies could be further increased in earlier periods by adding more cross-dated series. We note that an increase of tree-ring widths and consequently indices was observed during the de-trending procedure for the last six decades in all chronologies. The most common periods showing a TRW increase were 1965-1970, 1978-1981, and 1987-1991, whereas the periods with radial growth decrease were different between site chronologies. The radial growth which increased during the second half of the twentieth 
century has been found in other long tree-ring chronologies and is often attributed to a changing temperature regime [28-30]. Based on CRU climatic data, the common periods associated with mean temperature's rising spanning from 1981 to 2010, while the periods with significant decrease of precipitation records were 1981-1990 and 2010-2014 respectively (Figure 5). These are the first chronologies from Kosovo, but there are also some other built earlier in Italy and the Balkan Peninsula. In comparison, the longest nearby $P$. heldreichii chronologies span periods of 1392 years (617-2008) were found in Albania [14], 762 years (1243 to 2004) in Greece [31], 758 years (1250 to 2008) in Bulgaria [11], and 827 years (1148 to 1974) in Southern Italy [32].

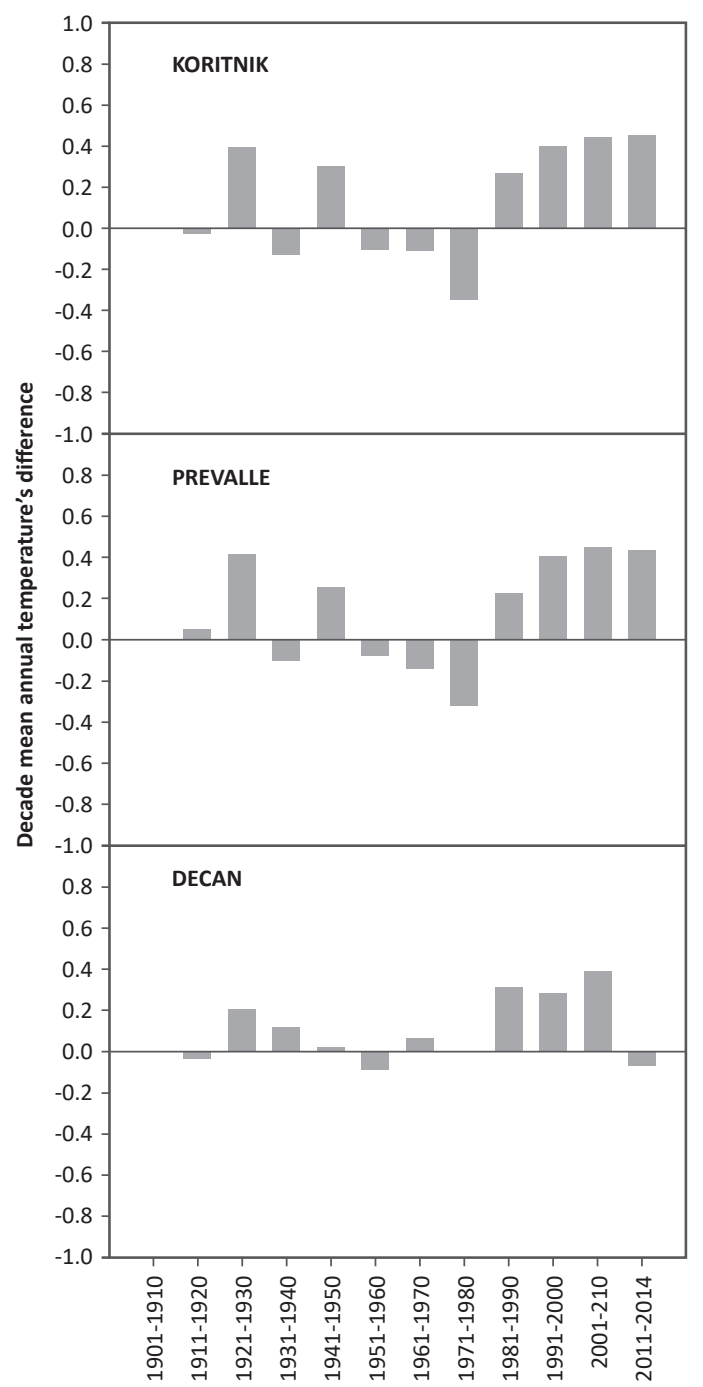

We tried to download these chronologies from International Tree-Ring Data Bank (http://hurricane.ncdc.noaa. gov/pls/paleox/f?p=518:1:3874104498420267:::APP:PROXY TOSEARCH:18) aiming to compare them with ours, but none was available on the website.

\section{Growth-Climate Relationship}

Despite the observed climate signal, the response to climate of the three site chronologies was not particularly strong or robust. The low correlation values could at least partly be related to the sparse availability of regional meteorological station data for Kosovo high-elevation sites and also for the whole Balkan region, resulting in a limited representation of

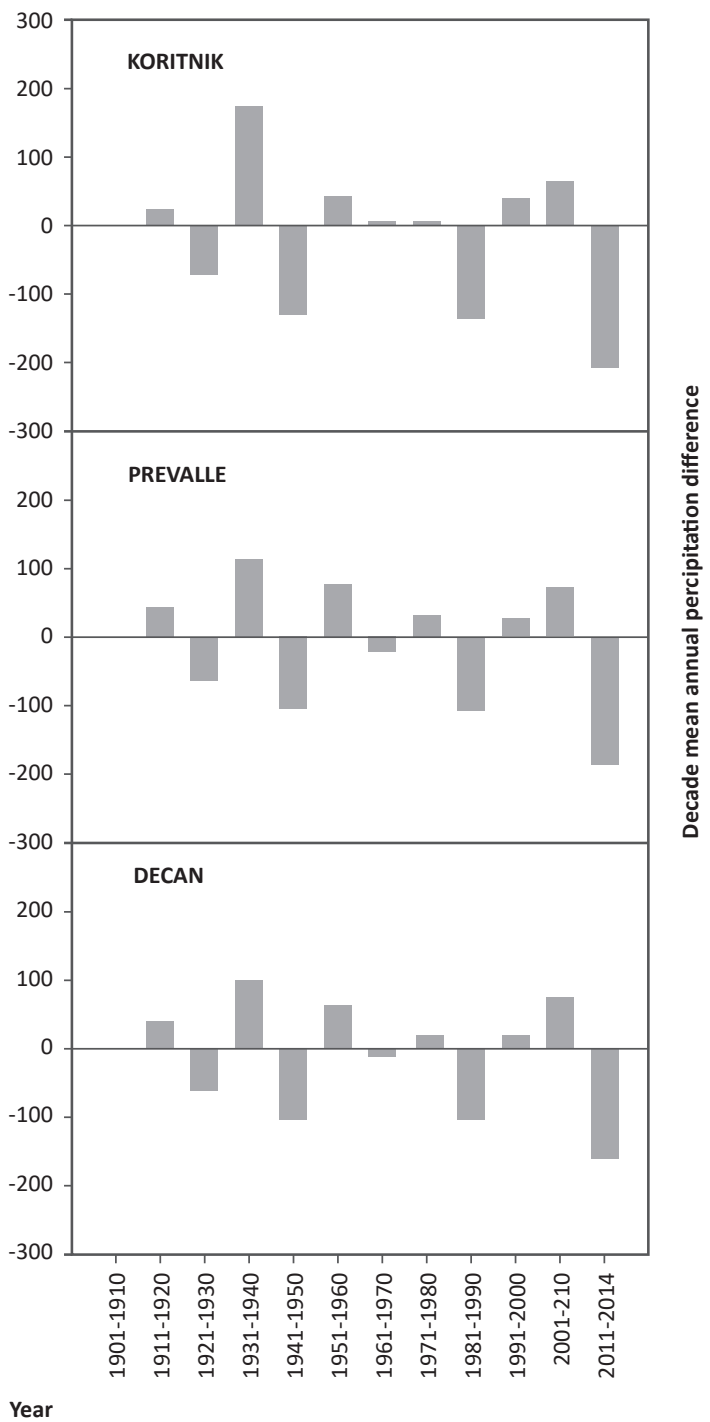

FIGURE 5. Decennial successive differences between mean annual temperatures and mean annual sum of precipitation for the period 1901-2014 (including the period 1951-2013 used as reference in bootstrap correlation analysis) 
the gridded CRU data for the study region. In all studies, the correlations between TRW and various instrumental climate data (monthly temperature and precipitation) were relatively weak and not robust over the $20^{\text {th }}$ century proxy-target period. Even for the western Mediterranean basin, similar results based on three conifer species from the Pyrenees were reported [33].

We found strong relationships between tree-ring chronologies and summer precipitation of the current growing year for DE and July precipitation for the PRE site. The location of these stands in high mountainous areas is positively affected by local humid currents helping trees to avoid the negative effects of summer droughts [17]. The strong relationship between $\mathrm{KO}$ residual chronology and climate conditions of the years prior to the growth indicates that in this tree-line location, the growing period is relatively short and the most active tracheid formation occurs at the beginning of summer [34]. Therefore, for the production of wide tree rings the combination of early cambial activity start with enough available resources, i.e. stored carbohydrates and other substances produced in the previous growth period, and favorable climate conditions during the late spring and early summer months of the growth year is needed. The effect of climate in the previous year is expressed by strong first-order autocorrelation often found in tree-line trees [35] and also in our series.

Significant correlations with precipitation in certain months of the previous growing season were found at all sites. The persistence of this climatic signal in the subsequent years is linked with soil moisture reserves for the subsequent growing season. Our study revealed that young trees in the $\mathrm{KO}$ site growing under drier conditions were more sensitive to summer drought stress, as reflected by the negative correlations with June temperatures and positive correlations with July and August precipitation. Tree age is important not only for tree-ring formation but also for growing trends and should be taken into consideration when exploring the growth-climate relationship. Previous studies have shown that the duration of wood formation in conifers was shorter in old than in young trees [36]. This study reported that young trees were characterized by an earlier onset of xylogenesis, a longer growing season and a higher growth rate, resulting in a higher number of xylem cells. One possible explanation for the earlier onset of xylogenesis in young trees is that the base of the stem is closer to the crown and hence to the source of auxin than in old trees [16]. Moreover older trees have larger diameters and thicker barks, which could negatively influence the spring dynamics of stem warming. Compared to young trees, old trees have a higher hydraulic resistance and lower photosynthetic rates, which might potentially increase the climatic sensitivity reflected in $P$. heldreichii growing at DE site $[16,37,38]$.

Positive correlations with current winter temperatures reported at all three sites showed that mild winters have a positive influence on snow melting or rainfall. From a physiological point of view, winter temperatures cannot directly influence cambial activity since the trees are dormant. However, during warmer winters, more precipitation falls as rainfall, rather than as snow [39]. In our case, it is more probable that precipitation in cases with warmer winter temperatures is in the form of wet snow, which on its side is less prone to wind transport and immediate sliding along steep slopes and therefore could contribute to a deeper snow cover. This can provide more soil moisture after snowmelt and could be a prerequisite for increased cambial activity given that other conditions are favorable.

We expected a stronger thermal signal because the research sites were situated at high elevation and the low temperature is assumed to be the main driver for tree growth. Although sampling in Kosovo was conducted at the highest forested elevations (up to $1945 \mathrm{~m}$ a.s.l.), our sampled sites might not fully represent typical tree-line conditions. For instance, the thermal tree line of Pinus heldrechii at the Olymp (Greece) ranges from 2200 to $2400 \mathrm{~m}$ a.s.l. with the krummholz zone even reaching elevations of 2500 to $2700 \mathrm{~m}$ a.s.l [12]. Körner [40], on the other hand, stated that Mediterranean tree-line sites do not show a clear temperature controlled growth pattern compared to the Alpine region and that it is questionable if sampling at the upper zone provides more defined growth control. Therefore, follow-up studies should be based on tree-ring parameters such as maximum latewood density and stable isotope ratios that are expected to be more climate sensitive in the area.

\section{CONCLUSIONS}

The first TRW chronologies from Kosovo are an important step towards a denser tree ring network in the Balkan region. Growth-climate relationships indicated that $P$. heldreichii's growth does not depend only on one single dominant factor, but on various combinations of precipitation and temperature resulting in different climatic sensitivity. Our results provide an important basis for additional tree-ring parameters such as maximum latewood density and stable isotope ratios to be processed, improving the understanding about $P$. heldreichii's response versus site conditions.

\section{Acknowledgements}

We thank two anonymous reviewers for their comments and suggestions which improved the manuscript quality. This study was supported by the Agricultural University in Tirana. We thank Mr. Arben Q. Alla who helped in core collection and Mr. Saimir Beqaj and Albert Buzali for their support during cores preparation. 


\section{REFERENCES}

1. NELSON EJ, KAREIVA P, RUCKELSHAUS M, ARKEMA K, GELLER G, GIRVETZ E, GOODRICH D, MATZEK V, et al,. 2013 Climate change's impact on key ecosystem services and the human well-being they support in the US. Front Ecol Environ 11 (9): 483-493. DOI: http://dx.doi.org/10.1890/120312

2. WOLKOWICH EM, COOK BI, ALLEN JM, CRIMMINS TM, BETANCOURT JL, TRAVERS SE, PAU S, REGETZ J, et al., 2012 Warming experiments underpredict plant phenological responses to climate change. Nature 485: 494-497. DOI: http://dx.doi.org/10.1038/nature11014

3. MALCOLM JR, MARKHAM A, NEILSON RP, GARACI M 2002 Estimated migration rates under scenarios of global climate change. J Biogeogr 29 (7): 835-849. DOI: http:// dx.doi.org/10.1046/i.1365-2699.2002.00702.x

4. THEURILLAT JP, GUISAN A 2001 Potential impact of climate change on vegetation in the European Alps: a review. Climatic Change 50 (1): 77-109. DOI: http://dx.doi. org/10.1023/A:1010632015572

5. GRIFFITHS HI, KRYSTUFEK B, REED JM (eds) 2004 Balkan Biodiversity: Pattern and process in the European hotspot. Springer, Dordrecht, The Netherlands, 357 p. DOI: http:// dx.doi.org/10.1007/978-1-4020-2854-0

6. XOPLAKI E, GONZALEZ-ROUCO JF, LUTERBACHER J, WANNER H 2003 Mediterranean summer air temperature variability and its connection to the large-scale atmospheric circulation and SSTs. Clim Dynaam 20 (7): 723-739. DOI: http://dx.doi.org/10.1007/s00382-003-0304-x

7. XOPLAKI E, GONZALEZ-ROUCO JF, LUTERBACHER J, WANNER H 2004 Wet season Mediterranean precipitation variability: influence of large-scale dynamics and trends. Clim Dynam 23 (1): 63-78. DOI: http://dx.doi.org/10.1007/ s00382-004-0422-0

8. NICAULT A, ALLEAUME S, BREWER S, CARRER M, NOLA P, GUIOT J 2008 Mediterranean drought fluctuations during the last 500 years based on tree-ring width data. Clim Dynam 31 (2): 227-245. DOI: http://dx.doi.org/10.1007/ S00382-007-0349-3

9. QIRIAZI P, SALA S 2000 Environmental problems of Albania. In: Buchroithner MF (ed) Remote sensing for environmental data in Albania: a strategy for integrated management. Springer, Dorbrecht, The Netherlands, pp 13-30. DOI: http://dx.doi.org/10.1007/978-94-011-4357-8 4

10. PANAYATOV M, BEBI P, KRUMM F, YURUKOV S 2009 Pinus peuce and Pinus heldreichii tree rings as a key to past mountain climate in Southeastern Europe. In: Kaczka RJ, Malik I, Owczarek P, Gärtner H, Heinrich I, Helle G, Schleser $\mathrm{G}$ (eds) Tree rings in archaeology, climatology and ecology, TRACE 7: 71-77

11. PANAYATOV M, BEBI P, TROUET V, YURUKOV S 2010 Climate signals in Pinus peuce and Pinus heldreichii tree-ring width chronologies from the Pirin Mountains in Bulgaria. Trees 24 (3): 479-490. DOI: http://dx.doi.org/10.1007/s00468010-0416-y

12. BRANDERS R 2007 Waldgrenzen griechischer Hochgebirge: unter besonderer Berücksichtigung des Taygetos, Südpeloponnes [Timberlines of Greek high mountains: With special regard to the Taygetos mountains, southern Peloponnese (forest dynamics, fir die-back, dendrochronological research on Pinus nigra)] (in German with English summary). PhD thesis, University of Erlangen, Germany, $259 p$

13. GRIGGS C, DEGAETANO A, KUNIHOLM P, NEWTON M 2007 $A$ regional high-frequency reconstruction of May-June precipitation in the north Aegean from oak tree rings, $A D$ 1089-1989. Int J Climatol 27 (8): 1075-1089. DOI: http:// dx.doi.org/10.1002/joc.1459
14. SEIM A, BUNTGEN U, FONTI P, HASKA H, HERZIG F, TEGEL F, TROUET V, TREYDTE K 2012 Climate sensitivity of a millennium-long pine chronology from Albania. Clim Res 51 (3): 217-228. DOI: http://dx.doi.org/10.3354/cr01076

15. TROUET V, PANAYOTOV M, IVANOVA A, FRANK D 2012 A Pan-European summer teleconnection mode recorded by a new temperature reconstruction from the eastern Mediterranean (1768-2008). Holocene 26: 709-721. DOI: http://dx.doi.org/10.1177/0959683611434225.

16. ROSSI S, DESLAURIERS A, ANFODILLO T, CARRER M 2008 Age-dependent xylogenesis in timberline conifers. New Phytol 177 (1): 199-208. DOI: http://dx.doi.org/10.1111/ j.1469-8137.2007.02235.x

17. TODARO L, ANDREU L, D'ALESSANDRO CM, GUTIERREZ E, CHERUBINI P, SARACINO A 2007 Response of Pinus leucodermis to climate and anthropogenic activity in the National Park of Pollino (Basilicata, Southern Italy). Biol Conserv 137 (4): 507-519. DOI: http://dx.doi.org/10.1016/j. biocon.2007.03.010

18. FRITTS HC 1976 Tree Ring and Climate. Academic Press, New York, USA, $567 \mathrm{p}$

19. SCHWEINGRUBER FH 1988 Tree Rings. Basics and Applications of Dendrochronology. springer, Dordrecht, The Netherlands, 276 p. DOI: http://dx.doi.org/10.1007/97894-009-1273-1

20. STOKES MA, SMILEY TL 1968 An introduction to tree ring dating. University of Chicago Press, Chicago, USA, $73 p$

21. HOLMES RL 1983 Computer-assisted quality control in tree-ring width dating and measurement. Tree-Ring Bull 43: 51-67.

22. COOK ER 1985 A time series analysis approach to the tree-ring width standardization. PhD Thesis, University of Arizona, USA

23. COOK ER, HOLMES LR 1999 Users manual for program ARSTAN. Laboratory of Tree-ring width Research, University of Arizona. Tucson, Arizona, USA.

24. COOK ER, PETERS K 1997 Calculating unbiased tree-ring width indices for the study of climatic and environmental change. Holocene 7 (3): 361-370. DOI: http://dx.doi. org/10.1177/095968369700700314

25. WIGLEY TML, BRIFFA KR, JONES PD 1984 On the average of correlated time series, with applications in dendroclimatology and hydrometeorology. J Clim Appl Meteorol 23: 201-213. http://dx.doi.org/10.1175/15200450(1984)023<0201:OTAVOC>2.0.CO;2

26. MITCHELL TD, JONES PD 2005 An improved method of constructing a database of monthly climate observations and associated high-resolution grids. Int J Climatol 25 (6): 693-712. DOI: http://dx.doi.org/10.1002/joc.1181

27. BIONDI F, WAIKUL K 2004 DENDROCLIM2002: A C++ program for statistical calibration of climate signals in tree-ring width chronologies. Computers \& Geosciences 30 (3): 303-311. DOI: http://dx.doi.org/10.1016/j. cageo.2003.11.004

28. D'ARRIGO R, WILSON R, LIEPERT B, CHERUBINI P 2008 On the 'Divergence Problem' in Northern Forests: a review of the tree ring evidence and possible causes. Glob Planet Change 60 (3-4): 289-305. DOI: http://dx.doi. org/10.1016/i.gloplacha.2007.03.004

29. ESPER J, NIEDERER R, BEBI P, FRANK D 2008 Climate signal age effects - evidence from young and old trees in the Swiss Engadin. For Ecol Manag 255 (11): 3783-3789. DOI: http://dx.doi.org/10.1016/j.foreco.2008.03.015

30. OBERHUBER W, KOFLER W, PFEIFER K, SEEBER A, GRUBER A, WIESER G 2008 Long-term changes in tree-ring width climate relationships at Mt. Patscherkofel (Tyrol, Austria) since the mid 1980s. Trees 22 (1): 31-40. DOI: http://dx.doi. org/10.1007/s00468-007-0166-7 
31. KUNIHOLM PI, STRIKER CL 1983 Dendrochronological Investigations in the Aegean and Neighboring Regions, 1977-1982. J Field Archaeol 10 (4): 411-420. DOI: http:// dx.doi.org/10.2307/529464

32. SERRE-BACHET F 1985 Une chronologie pluriseculaire du Sud de I'Italie. Dendrochronologia 3: 45-66

33. BUNTGEN U, FRANK D, TROUET V, ESPER J 2010 Diverse climate sensitivity of Mediterranean tree-ring width and density. Trees 24 (2): 261-273. DOI: http://dx.doi. org/10.1007/s00468-009-0396-y

34. ROSSI S, DESLAURIERS A, ANDOFILLO T, MORIN H, SARACINO A, MOTTA R, BORGHETI M 2006 Conifers in cold environments synchronize maximum growth rate of treering width formation with day length (2006). New Phytol 170 (2): 301-310. DOI: http://dx.doi.org/10.1111/j.14698137.2006.01660.x

35. FRITTS HC, SMITH DG, CARDIS JW, BUDELSKY CA 1965 Treering characteristics along a vegetation gradient in Northern Arizona. Ecology 46 (4): 393-401. DOI: http://dx.doi. org/10.2307/1934872
36. CARRER M, URBINATI C 2004 Age-dependent tree ring growth responses to climate of Larix decidua and Pinus cembra in the Italian Alps. Ecology 85 (3): 730-740. DOI: http://dx.doi.org/10.1890/02-0478

37. MENCUCCINI M, MARTINEZ-VILATA J, VANDERKLEIN D, HAMID HA, KORAKAKI E, LEE S, MICHELIS B 2005 Sizemediated ageing reduces vigour in trees. Ecol Lett 8 (11): 1183-1190. DOI: http://dx.doi.org/10.1111/j.14610248.2005.00819.x

38. MERIAN P, LEBOURGEIOS F 2011 Size-mediated climategrowth relationships in temperate forests: a multi-species analysis. For Ecol Manag 261 (8): 1382-1391. DOI: http:// dx.doi.org/10.1016/j.foreco.2011.01.019

39. IPCC 2007 Climate Change 2007: The Physical Science Basis. In: Solomon S, Qin D, Manning M, Chen Z, Marquis $\mathrm{M}$, Averyt KB, Tignor M, Miller HL (eds) Contribution of Working Group I to the Fourth Assessment Report of the IPCC. Cambridge University Press, Cambridge, UK, 996 p

40. KÖRNER C 1998 A re-assessment of high elevation treeline positions and their explanation. Oecologia 115 (4): 445459. DOI: http://dx.doi.org/10.1007/s004420050540 